\title{
Finding voices in the floods of Freedom Hill: innovating solutions in Princeville, North Carolina
}

\author{
Cynthia A. Grace-McCaskey ${ }^{1}$ (1) $\cdot$ Susan C. Pearce ${ }^{2} \cdot$ Lynn Harris $^{3} \cdot$ Mamadi Corra $^{2} \cdot$ Kayla J. Evans $^{4}$
}

Accepted: 28 April 2021 / Published online: 21 May 2021

(c) AESS 2021

\begin{abstract}
Princeville, NC, is the oldest town chartered by Blacks in America. Founded as Freedom Hill in 1865 and incorporated as Princeville in 1885, the town continues to be predominantly African American today. Built on the unwanted and flood-prone lands adjacent to the Tar River, Princeville has flooded multiple times throughout its history, including after Hurricane Floyd in 1999 and Hurricane Matthew in 2016. Because of the town's historical significance, residents and town officials alike have been reluctant to accept offers for widespread buyouts from the government. Despite having limited financial resources and political clout, the town has developed a unique approach to managed retreat while rebuilding from Matthew-one that emphasizes the importance of historical sites while also recognizing the need to relocate residents out of harm's way from future floods. This manuscript uses a historical and narrative approach to examine how Princeville's unique history, and the relationship between the town and the Tar River, play important roles in the town's decisions regarding retreat and redevelopment in the aftermath of major flooding events. We highlight the voices of current residents, including leaders, as well as the structural and cultural conditions that both constrain and enable the town's collective agency. While focused on the present day, this case study is historically informed, using oral histories and archival documents.
\end{abstract}

Keywords Flooding $\cdot$ Princeville $\cdot$ Disaster recovery $\cdot$ Black towns $\cdot$ Environmental justice $\cdot$ African American history

\section{Introduction}

Princeville, NC, is the oldest town chartered by Blacks in America. ${ }^{1}$ The town was founded in 1865 as Freedom Hill and incorporated as Princeville in 1885, named after one

\footnotetext{
1 Although at least one other American town claims to be the first incorporated Black town-Brooklyn, Illinois (also called "Lovejoy"), which was an antebellum settlement that was incorporated postbellum, in the year 1873 (Cha-Jua 2000) - it is outside of the scope of this project to make a determination on this question. To our knowledge, Princeville is the first postbellum incorporated Black town (State of North Carolina 1885).
}

Cynthia A. Grace-McCaskey gracemccaskeyc15@ecu.edu

1 Department of Anthropology \& Coastal Studies Institute, East Carolina University, Greenville, NC, USA

2 Department of Sociology, East Carolina University, Greenville, NC, USA

3 Department of History, East Carolina University, Greenville, NC, USA

4 Department of Anthropology, East Carolina University, Greenville, NC, USA of the town's earliest residents and accomplished carpenter, Turner Prince. The town sits along the Tar River in eastern North Carolina and has flooded numerous times due to its low elevation. The town received national attention in 1999, when it flooded due to heavy rains from Hurricane Floyd. Although the state of North Carolina offered the widespread buyout of homes that flooded through the Federal Emergency Management Administration's (FEMA's) Hazard Mitigation Grant Program (HMGP), the town decided not to accept the offer and to rebuild instead, stating that the town's historical and cultural significance was too important to abandon. In 2016, the town flooded again due to rains from Hurricane Matthew. Although at the time of writing this manuscript the status of most of the properties flooded by Matthew remains undecided, the town is collectively promoting a proactive approach of managed retreat and relocation that will preserve the historical importance, sense of place, and connections to the historically significant lands, while also proactively promoting adaptation, so future floods do not continue to threaten the entire town. We take a historical and narrative approach to examine how Princeville's unique history, and the relationship between the town and 
the Tar River, play important roles in the town's decisions regarding retreat in the aftermath of major flooding events.

Anthropogenic climate change is bringing more intense storms and sea-level rise, increasing the frequency of flood events (Lall et al. 2018; Patricola and Wehner 2018). The recently published North Carolina Climate Risk Assessment and Resilience Plan (NCDEQ 2020) predicts increases in the frequency and intensity of extreme precipitation events in coming years, likely leading to more frequent riverine flooding. North Carolina has been impacted by several extreme weather events in recent years, including Hurricane Matthew (2016), Hurricane Florence (2018), and Hurricane Dorian (2019). While storms like these bring damage and destruction to coastal communities from storm surge, high winds, and torrential rain, the extremely high precipitation that falls further inland leads to riverine flooding, often peaking several days after the storms have passed.

After Hurricanes Fran (1996) and Floyd (1999) flooded properties in communities throughout eastern North Carolina, the state used HMGP funds administered by FEMA to acquire 4800 properties (NCEM 2017a). This is a common environmental relocation strategy used in the USA (Martin 2019; Elliott et al. 2020). The purpose of such "buyout" programs is to remove residences and other structures from areas at risk of flooding, turning those properties into open space, thereby preventing future costs related to disaster recovery. To do so, buyout programs offer residents a payout based on property value that can assist those who volunteer to do so in relocating to a less risky area. Although buyout programs may be deemed effective in some communities if they successfully relocate residents out of flood-prone areas, recent scholarship illuminates the negative consequences these programs can have on individuals and communities receiving buyouts and those living in surrounding communities, as well as the disproportionate manner in which marginalized communities and people of color are impacted by these programs (Binder et al. 2019; Martin 2019; Siders 2019a; Siders and Keenan 2020). Additionally, recent research highlights the complex mix of social, political, institutional, and economic inequities that impact which neighborhoods and communities are targeted for buyouts at the federal and local levels, whether residents accept buyout offers, and the ease and success with which buyouts are administered (Binder et al. 2015; de Vries 2017; Mach et al. 2019; Siders 2019a; Elliott et al. 2020).

In most cases in the U.S., buyout programs are administered after disaster events such as floods, storms, or fires, and an increasing body of literature focuses on what impacts whether individuals and communities rebuild or relocate. Research suggests that individuals' and communities' sense of place and place attachment play an important role in post-disaster decision making regarding whether to rebuild, as well as in the development of recovery and adaptation strategies (Chamlee-Wright \& Storr 2009; Amundsen 2015; Clarke et al. 2018; Greer et al. 2020). The literature surrounding place attachment is broad and interdisciplinary, stemming from human geography, environmental psychology, anthropology, and sociology, and researchers have proposed numerous ways to conceptualize and measure place attachment and related concepts such as sense of place and place identity (Trentelman 2009; Lewicka 2011; DevineWright 2013; Greer et al. 2020). Here, we take a broad approach, understanding place attachment to be "the emotional bond to an area where people prefer to remain and where they feel comfortable and safe" (Seebauer and Winkler 2020:3). Place identity "covers how a particular place is an inextricable part of personal identity and self-image" (Seebauer and Winkler 2020:3). Studies specifically focusing on Princeville after the flooding from Floyd highlight the substantial role that residents' sense of place and connections of community and individual identities to the unique history of the town played in decisions to rebuild (Yoon 2009; Phillips et al. 2012).

As the town's citizens are displaced and separated, the sense of community and shared history is typically lost, something that could have dire consequences for a town with such historical and cultural significance as Princeville. In fact, Princeville's unique cultural identity and historical significance repeatedly play primary roles when the town's leaders make decisions about the future, despite the continued threats from its surrounding physical environment. Clearly, human populations settle, relocate, or remain based on a confluence of environmental, social, economic, and political factors, resulting in a "dynamic relationship between the social and the spatial" (Armstrong-Fumero 2017:5). This complex mix also defines Princeville's own past and present. While such factors contribute in varying ways to either constrain or enable the town's continued settlement, it is the historical ties and cultural self-identity that greatly influence decisions over whether to leave or remain. This illustrates the power that symbolic meaning, or "intangible cultural heritage" (Armstrong-Fumero 2017), plays for communities, despite overwhelming threats to physical continuation. Further, for a community like Princeville, the weighty history of enslavement and White supremacy infuses this shared meaning with additional significance. Princeville's experience contributes to notions that place attachment can actually work as a driver of adaptation, not only as a factor that reduces the community's willingness and ability to retreat and adapt (Amundsen 2015).

In this article, we take a historical and narrative approach to examine how Princeville's unique history, and the relationship between the town and the Tar River, play important roles in the town's decisions regarding retreat in the aftermath of major flooding events. First, we draw on historical documents, personal accounts, photographs, and other 
records to describe the founding of Princeville in the floodprone lands adjacent to the Tar River and to situate the town in post-Civil War eastern North Carolina. Next, using data collected via oral history and semi-structured interviews conducted with town leaders and long-term residents $(n=13$, collected in 2019 and 2020, employing purposive and snowball sampling strategies), informal interviews, participant observation, and newspaper records, we describe the town's experiences with flooding events and their aftermath since Hurricane Floyd in 1999. We also describe Princeville's ongoing redevelopment after flooding due to Hurricane Matthew in 2016 and the town's unique approach to managed retreat-one that emphasizes the importance of historical sites while also recognizing the need to relocate residents out of harm's way from future floods. Data were collected during numerous visits to Princeville in 2019 and 2020, with some interviews and conversations taking place virtually after restrictions were put into place due to COVID-19. All interviews were recorded, transcribed, and analyzed for significant themes using inductive and deductive techniques (Bernard 2017). Presenting the results via a narrative and highlighting the voices of residents and leaders allow for a compelling recount of Princeville's story and position it within the contemporary context of managed retreat in the USA, without losing sight of the critically significant history of the town.

\section{Princeville, NC: historical context}

With predominantly African American populations, "Black towns" are settlements established by or for African Americans either during or after the period of legal slavery in the USA. Also known as "Freedmen's towns," "Freedom towns," or "All-Black towns," well over a thousand such towns have existed throughout the USA (Taylor 1995), as many African American migrants from the southeast and elsewhere tried to establish municipalities on their own terms (Crockett 1979). Many were ultimately transient, but at least 88 , and perhaps as many as 200 , Black towns were established by African American town promoters throughout the USA during the late nineteenth and early twentieth centuries (Taylor 1995). Having emerged during the post-Civil War reconstruction era, these towns offered spaces in which the formerly enslaved could control their own futures rather than serve former masters (Smallwood 1981). As such, these towns provided African Americans the opportunity to escape racial oppression, control their economic destinies, and prove Black capacity for self-government.

One of those towns that still survives is Princeville. Its story begins just after the Civil War. By 1865, Union troops had established a temporary encampment just outside Tarboro, NC, having occupied the town. The site became a refuge and beacon for still-enslaved people who heard they could find relative freedom and safety there under the protection of Union forces. After the Civil War ended, many of the formerly enslaved people decided to remain on the land to establish their own settlement. Two White planters held the deeds to this land prior to the war, but did not make an effort to evict the new settlers, possibly due to the land's vulnerability to flooding (Mobley 1986:341). The settlers called their new community "Freedom Hill," named for the elevated parcel where a Union soldier had stood to share news of the Emancipation Proclamation. The town was formerly incorporated as Princeville in 1885, making it the first incorporated Black town in the USA (Mobley 1986).

As Freedom Hill and, subsequently, Princeville, took root, an economic interdependence developed with the neighboring, White-majority town Tarboro, which had been the seat of local plantations. Tarboro began to develop a manufacturing sector during the twentieth century, which provided employment to Princeville residents and helped support Princeville's continuity. That interdependence, however, did continue to reproduce historical racial-economic hierarchies, with Princeville remaining the less-privileged of the two, despite the town's own local businesses constituting a "Black Wall Street."

In spite of its prominent history, there is little collective public memory of the town and its origins. The National Museum of African American History and Culture in Washington, DC, honors the history of Black towns in one of its historical exhibits and names Eatonville, FL, as the first Black town. Eatonville waved this banner until recently, when North Carolina Museum of History curator Earl Ijames uncovered evidence that Princeville was chartered in 1885, two years before Eatonville (State of North Carolina 1885; Adkins 2020). The town's residents often cite this firstness as a key point of pride: a shared collective memory of the town's significance. During the 2020 Founder's Day celebration, Princeville Mayor Bobbie Jones observed, "We are the only town that can say we are the oldest town in America chartered by Blacks" (Adkins 2020).

This claim to originality animates many residents' identities, as they recall histories of ancestral self-determination. Stories of this determination include not only recovery from floods but resistance to White supremacist forces who worked to diminish Princeville's political agency and abolish the town's charter (Mobley 1986:371). Princeville describes itself, in fact, as "The Town that Defied White Supremacy" (Town of Princeville n.d.). Residents often recite with gratitude accounts of the hard work of Turner Prince, who physically built the town's early structures, creating a community from scratch. Moreover, such shared collective memories often intersect with personal memory for those who trace their ancestry to the founding years. 
This intersecting personal and shared cultural meaning is frequently vocalized in discussions over whether to rebuild after a devastating flood.

In Princeville collective memories, the Tar River manifests a Janus face. While it certainly threatens life, home, and livelihood and is clearly feared during hurricane season, it has also offered symbolic power throughout the town's existence. The river was traditionally a place for Christian baptisms for local churches, including those of congregants from Mount Zion Primitive Baptist Church, which is the oldest historic building in Princeville today. It was erected in 1896 with a stone statue of Abraham Wooten, the founding elder, attached to the top front step (Mobley 1986:346). From the 1890s to the 1950s, congregants of this and other local African American churches accessed the river for baptismal ceremonies, wearing white religious robes, at a location near the bridge to Tarboro (URS Group Inc 2001; Cecelski 2007).

Shiloh Landing is another site that illustrates the historically complex relationship between Princeville residents and the Tar River. Shiloh Landing is a sharp bend in the Tar River two miles above Tarboro. Today, the site appears to be no more than a popular fishing spot, and its deeply significant history is both unmarked and unrecognized. In the 1800 s, however, it played an important role in the production of cottonseed oil by the Tar River Oil Company because it could accommodate steamboat access. The company's cottonseed mill was located at Shiloh Landing, and the steamer Shiloh collected bags of seed at landings along the river, carrying them upriver to the mill. After the mill crushed the seed, the steamers carried the cottonseed oil and other by-products back down the Tar to Washington, NC (Wyllie 2012; Cecelski 2019).

According to local historian Rudolph Knight, however, Shiloh Landing has a different symbolic meaning for African Americans in Edgecombe County. Citing local oral traditions, Knight recalls that the landing was the site where antebellum cotton planters arranged with local agents to acquire enslaved laborers from the slave markets in Richmond, VA (Knight and Auld 2013; Cecelski 2019). The presence of enslaved labor in the area and transported Tar River boats dates back much earlier. From the last decades of the late 1700s, wharves were constructed along the Tar River for offloading shipments and enslaved laborers. Flatboats and rafts were of very shallow draft and carried large quantities of cotton, naval stores, tobacco, and human freight to Washington, NC. They floated downriver with the current. In many cases, enslaved boatmen steered them with long stern oars. According to stories in the African American community (including those of Knight's own family), the agents at Shiloh Landing would go to Richmond, purchase the enslaved laborers, and return by river (Listening to History 2003; Knight and Auld 2013; Cecelski 2019).
Thus, Shiloh Landing is believed to have been a point of delivery for enslaved people who were likely sold in Tarboro. In the 1790s, there was a slave market in Tarboro (Turner and Bridgers 1850:176), and by 1800 , the courthouse in Tarboro, as in other port cities, served as the venue to free enslaved individuals; make sales of women, men, and children of African descent; or hire them out for services (Edgecombe County Census 1790; Turner and Bridgers 1850:166). Shiloh Landing, therefore, represents a landscape feature of eastern North Carolina's slave economy, and families in Princeville today trace their own Edgecombe County lineage to Shiloh Landing by way of the slave trade.

This background situates Princeville as a central historical actor-not only for its denizens and its corner of Eastern North Carolina, but for the state of North Carolina more generally, if not the nation. It further illustrates the human connection to the landscape that animates continued loyalty to the place across generations. Yet that loyalty has been frequently tested, as its vulnerable physical position attests. The next section narrates this experience.

\section{Flooding and rebuilding in Princeville}

Due to Princeville's location in the floodplain of the Tar River, the town has experienced widespread flooding several times throughout its history. Prior to 1999 , the town had not flooded since 1958, largely due to the levee built and completed by the Army Corps of Engineers (ACE) in 1967 to protect the town from severe flooding (ACE 2015). On September 16, 1999, however, Hurricane Floyd made landfall in eastern North Carolina, bringing with it approximately 15 inches of rain to Edgecombe County. Coming less than two weeks after Hurricane Dennis, the water levels of the Tar River were already higher than usual, which resulted in the river cresting at nearly 42 feet (NCEM 2017b). The levee failed, leaving the town flooded for nearly two weeks. Hurricane Floyd damaged or destroyed nearly all 1000 residential structures in Princeville, but due to advance flood warnings, all residents were evacuated, and no human lives were lost (ACE 2015).

The North Carolina Emergency Management approached the town of Princeville with an offer of a complete buyout after the 1999 flood, but not everyone was in favor of the buyouts (Tilove 2005; Bidgood 2016; Martin 2019). Many residents felt that accepting a buyout meant giving up on the town that their ancestors fought hard to build. Moreover, as Martin (2019) explains, the town had another option because the ACE offered to rebuild the levee, and federal officials concluded that the repaired structure would keep Princeville out of the 100-year floodplain. Some town leaders, therefore, believed that they had a way to preserve the community, its residents, and its tax base while also protecting the town 
from future flooding. ${ }^{2}$ After much public debate, the board of commissioners voted against participating in the buyout program, with the Princeville Mayor at the time, Ms. Delia Perkins, casting the deciding vote (Bowman 1999; Martin 2019). She recalls, "My assessment was that there were not enough people who would be able to go out and start a new life without hardship, so I voted to stay, because I felt like the history of Princeville, and thinking about the citizens, and in their best interest, I decided to stay" (personal communication). Instead, the town accepted the offer from the ACE to rebuild the levee.

Although residents did not have the opportunity to receive a buyout, they were able to receive assistance from federal, state, and charitable disaster recovery funding sources. Prior to 1999, most Americans, even those from eastern North Carolina, had not heard of Princeville nor were they aware of its cultural and historical significance. In the aftermath of the flooding and the town's refusal to accept the buyout, the town received national attention. Residents recount memories of the celebrities who arrived to voice their support for Princeville due to its unique heritage, including The Artist (formerly known as Prince), Jesse Jackson, Reverend Al Sharpton, and President Clinton. Other national corporations made donations to help with the town's rebuilding, including American Airlines and The Lowe's Corporation (Phillips et al. 2012). Numerous faith-based groups played significant roles by volunteering to assist with cleanup and rebuilding. The President established the President's Council on the future of Princeville, citing the historic and cultural importance of the town, and praising the town's courage to rebuild (Clinton 2000). Ultimately, however, the council led to few concrete outcomes, and the town was again forgotten in the wake of the inauguration of President George W. Bush and the tragedy of September 11, 2001 (Chapman 2002).

Although some residents began to return to the town in November 1999, most of those who returned lived in trailers or campers on their properties or in nearby areas for months, or even years, while they rebuilt their homes. In 2000, the levee was restored to its original condition (ACE 2015). Most of the Princeville residents who returned felt that the restored levee would protect them from another catastrophic flood event like Floyd (Bidgood 2016; Martin 2019). Although it took many years, eventually Princeville's population returned to pre-Floyd levels, reflecting a combination of returning and new residents (U.S. Census Bureau 2020).

Just seventeen years after Princeville residents were assured that the damaging floods of Floyd would not happen

\footnotetext{
2 As Martin (2019) points out, however, an ACE report published in 2015 (ACE 2015) determined that the rebuilt levee did not keep Princeville out of the 100-year floodplain.
}

again, Hurricane Matthew made landfall in eastern North Carolina on October 8, 2016, bringing 10 inches of rain to Princeville and up to 20 inches of rain throughout the state (NCEM 2017b). The Tar River crested at over 36 feet, once again causing catastrophic flooding and damage to the town. Nearly 500 homes in Princeville flooded, and about 80 percent of the town was underwater for days (Coastal Resilience and Center 2020). In addition to residential structures, the fire department and town hall were also flooded (NCEM 2017b; Traylor 2017).

In the wake of the flooding from Matthew, the town was not faced with the same kind of community-level, allor-nothing decision regarding buyouts as they were after Floyd. Individual property owners had the choice to apply for any of the disaster recovery and mitigation grants for which they qualified. The recovery process, however, has been very slow. More than four years later, most residents whose homes were flooded by Matthew are still waiting to learn which mitigation options are available to them. Some residents whose homes were flooded in 1999 and again in 2016 have moved away, stating that they simply do not want to have to go through the economic and emotional stress from yet another flood. Others, however, have no intentions of leaving permanently, and the town is again going through the rebuilding process.

Research suggests that there are many factors that influence why people choose to stay and rebuild in the same places after catastrophic events like floods and whether they accept buyouts, including attachment to place, sense of community, local cultural norms, home ownership, income level, and age, to name just a few (Smith and Wenger 2007; Agyeman et al. 2009; Groen and Polivka 2010; Binder et al. 2015; Koslov 2016; Bukvic and Owen 2017; Colten et al. 2018; Siders 2019b). Studies specifically focusing on Princeville after the flooding from Floyd highlight the substantial role that Princeville's residents' sense of place and connection to the unique history of the town played in decisions to rebuild (Yoon 2009; Phillips et al. 2012; Martin 2019). Yoon (2009) describes it as an "invisible asset," and one that was not only unknown by most non-residents, but one that was overlooked by emergency management and rebuilding planners because of its lack of salience as a "community asset" with economic value.

Yoon (2009) also suggests that Princeville's rebuilding after the 1999 flooding highlights the importance for communities to have self-determination in terms of whether they choose to rebuild, that community members know what is best for their community and how to do it, and that communities' opinions about options post-disaster should be valued. Phillips et al. (2012) make a similar case, describing the deep-rooted connection Princeville's residents feel not only to the people in their community, but also to the actual land 
itself, its history, and what it represents for African American self-determination in the USA.

Martin (2019), examining the motivations for and outcomes of decisions regarding buyouts in marginalized communities, also found that Princeville's experience highlights the importance of history and memory in communities' decisions to accept buyouts or relocate. In Princeville, the buyouts were framed as an abandonment of the town's history. Conducting interviews after Hurricane Matthew again devastated Princeville in 2016, Martin found that those external to Princeville saw the decision made in 1999 against buyouts as a missed opportunity - if they had accepted the buyouts then, they would not have flooded again. Those who are part of the Princeville community, however, did not express regret regarding their decision to rebuild in place, only frustration that the levee failed to protect them (Martin 2019).

Oral history and open-ended interviews conducted by the authors in 2019 and 2020 supported these findings. When asked why they chose to stay in Princeville after the floods, residents reflected on their childhoods, their families, and their sense of belonging in and commitment to the historic town. During analysis, three main themes emerged, reflecting aspects of place attachment and place identity: (1) the town's historical importance; (2) importance for self-identity; and (3) dedication to the future of the town.

\section{Historical importance}

All interviewees described Princeville's historical significance as the first town chartered by Blacks in America as one of the reasons they supported rebuilding the town in the wake of the flooding from both Floyd and Matthew. Although Princeville received national attention after Floyd, many people—even in eastern North Carolina—still are not aware of the town's existence or significance. Many interviewees said, however, they are not willing to allow that significance to be washed away and forgotten. For many of them, their dedication to the town's history is inextricably linked to a deep connection to their ancestors and those from previous generations who built the town. As one town official explained:

We are a resilient people. I don't know of anybody that could have withstood' 99 and then 17 years later, 2016, and still not talking about leaving, not talking about uprooting, not talking about going anywhere. Because we realize what our forefathers went through in $1865 \ldots$ it's just mind boggling for me. For my forefathers to come across that Tar River Bridge as free people for the first time in their life with absolutely nothing, nothing but their God-given talents. And to swamp land, Princeville was absolutely swamp land. And to build Freedom Hill and to thrive in Freedom
Hill. We used to have, there was 35 black owned businesses in the town of Princeville in 1885. In 1885 they petitioned Congress. Look, we're going to change our name from Freedom Hill to Princeville after Turner Prince, and we want to be incorporated. To be initially told, "No, we'll give you the incorporation, but we're gonna change the name to Garfield after the $20^{\text {th }}$ President of the United States." And these people said, "No, we're gonna name it Princeville." And we know the outcome: We are Princeville. They used their blood, sweat, and tears to build houses, to build businesses. And for us to say, no because of what might happen in the future, we've got to turn our backs on what they did for us and move someplace else? Cannot happen. Cannot happen.

These sentiments were echoed by other interviewees, even while at the same time acknowledging that the town will continually be faced with risks from flooding. As another long-term resident of Princeville and current official said, speaking of the town's founders and their bravery when approaching the legislature:

I'm so proud of them because that was brave of them to stand and look a white man eyeball to eyeball and say, "No sir, we're gonna name it after Turner Prince." So because of their resilience, because of their bravery, today we live in Princeville, North Carolina, in the United States of America, the oldest town chartered by freed slaves. And that I'm so proud of. And then for somebody to say to me, "Why don't you guys just leave it?" So what you're asking me to do, sir, is to give up that, that our ancestors went through blood, sweat and tears, so that I could live [here]. You asking me to say, fine then. I can't do that. I don't want to do that. Now if there is a flood that really, really just washes us off of the map, while Princeville will forever be, we don't know what that future is, but until we get there, if that's something that has to happen, we'll be in Princeville.

Despite the challenges due to flooding, people are still committed to the town and its significance and live their lives each day with that deep connection to history and the heritage of Princeville in mind.

\section{Importance for self-identity}

Another theme that emerged from the interviews and other field methods was that Princeville is a central part of the identities of many community members. Not only is Princeville's history important to them, but many indicated that being a part of the Princeville community is a significant part of who they are as individuals. When asked why Princeville was important to him, one interviewee said: 
Princeville is who I am. I've lived many different countries, including the United States, several different states and towns. And I'm in Princeville. This is my destiny. This is who I am. This is where I'm supposed to be, what I'm supposed to be doing. I love being from Princeville. Wouldn't want it any other way.

Another interviewee described how it took him moving away from Princeville to join the service earlier in life to fully appreciate the connection he felt to the town:

When I went into the service, you know, with people from New York, Chicago and all those big places, Puerto Rico, Hawaii... you're sitting around eating or whatever you're doing, and say, where are you from? This guy says, "Chicago. Where you from?" "New York. Where are you from?" You know, I said, "Tarboro," and they were like... [pause], so that didn't work. Tarboro was too small. Next time I said, "Rocky Mount," they still scratched their heads. So next time I said, "about an hour away from Raleigh." But then, I didn't know the significant value of Princeville. 'Cause now, what I would say if they asked me? 'I'm from Princeville, North Carolina, the oldest town in America chartered by Blacks. Where are you from?".

These quotes highlight how important being from Princeville is to community members. While the town's history is, of course, significant, those with whom we spoke and interacted were not interested in preserving the town just for history's sake. Rather, their identities as individuals, family members, community members, and Black Americans are rooted in Princeville both geographically - in the unwanted swampland their ancestors turned into a prosperous town that they refuse to abandon-as well as in the sociocultural importance of being the first town founded by Blacks in America.

\section{Dedication to the future of the town}

The final theme we will discuss reflects interviewees' strong commitment to the future of Princeville. Although most individuals recognized the uncertainties that are inherent in the town's future, they also expressed their resolve to continue working for a better future in whatever form that might be. Despite the repeated tragedies of flooding events, the stories shared by those we interviewed are not sad. They are stories of hope and resilience and connections to the past, present, and future of the town. Those interviewed repeatedly described the sense of duty they felt not only to carry on the legacy of their ancestors by rebuilding (just as their ancestors did after floods), but also the sense of duty they felt toward future generations. This is illustrated in the following quote:
Resilience is not so much about yourself... resilience is making it good for somebody else. The rebuilding of Princeville, that we fight so hard for. I may not see that in my lifetime, but I want the younger generation to be able to sit and tell the story to somebody one day because they didn't give up on us. They didn't give up on Princeville. So today Princeville is flourishing like this because somebody stood through the test of time, resilient, so that we can enjoy it.

This sense of resilience, strengthened each time Princeville had no choice but to rebuild and adapt in the wake of floods, is as much connected to the challenges faced as the first town chartered by Blacks in America as it is to the Tar River itself. Moreover, the deep connections Princeville residents feel toward the land is precisely because of, not in spite of, the history of flooding.

The town recently acquired a 53-acre tract of land nearby that is just beginning to be developed (this is discussed further in the next section). Several interviewees are involved in the planning process for the development of this parcel and mentioned their visions for this land when discussing the future of the town. Their comments reflect a recognition that the rebuilding of Princeville must not abandon the original, yet flood-prone lands settled by the founders. Instead, they understand the importance of the connection between the original and new parcels to preserving the residents' sense of place. According to one of the town's leaders:

People don't understand this, but if you move the town hall, if you move the municipal facilities out of Princeville proper, wherever you take it, it's not Princeville. Princeville is where the blood, sweat, and tears were shed to make Princeville Princeville. And that's where we are now. Yes, we want to add more acreage, but we don't want to destroy Princeville proper. We have to maintain Princeville proper. We have to continue to be one of the 235 [Black] towns that's left. When you move everything out, you're destroying us.

This quote exemplifies the leaders' keen awareness that any future plans for the town must include and not abandon the original lands.

\section{Redevelopment, resilience, and the future of Princeville}

Princeville's leaders and many residents are committed to rebuilding and revitalizing the town, reimagining what a more resilient Princeville looks like, while highlighting the town's unique significance. As mentioned above, after the flooding from Hurricane Matthew in 2016, those whose homes were flooded could decide to participate in the hazard 
mitigation opportunities available for which they qualified (as opposed to the community-level decision that was made after flooding from Floyd in 1999). The process has been lengthy, however, and many homeowners are still waiting for the authorities to notify them for which strategies their properties qualify (e.g., elevation, buyout). The town is not sitting idly, however, while waiting for decisions to be made about residents' homes. Instead, the current town leadership is strongly forging ahead, and in collaboration with multiple agencies and organizations, ${ }^{3}$ they are diligently working to expand Princeville and increase the town's resilience. Current efforts by the town emphasize two aspects of a managed retreat strategy. First, realizing the likelihood that the town will flood again due to the increasing frequency of heavy rainfall events in the region, rebuilding efforts on the Town's original lands include making historic structures located in Princeville more resilient and flood-proof and designing land-use strategies that will celebrate the town's heritage and historic sites (Naylor et al. 2020). Second, the town is exploring development options in adjacent plots of land situated outside of the floodplain. As such, despite being a small, rural, Black town with few financial "assets" and a small staff, the town is refusing to give up on its historic significance and is continuing the process of self-determination established by the original settlers of Freedom Hill by proactively implementing strategies of managed retreat and adaptation.

One of the main reasons Princeville community members did not want to take buyouts after Hurricane Floyd in 1999 was that they felt they would be abandoning the lands, legacy, and hard work of their ancestors who founded the town, a factor that has continued to shape individual- and community-level decisions after Matthew. The town is cooperating with N.C. State University's Coastal Dynamics Design Lab and Conservation Trust for North Carolina in the development of a "Floodprint" for the town. This communityinformed design process combines properties bought out by FEMA (those bought out after Floyd or Matthew) with other publicly owned properties "to create a connected system of educational, recreational, and environmental amenities in areas that are otherwise vulnerable to environmental hazards, vacancy and neglect" (CDDL n.d.). The Floodprint plan was recently approved by the Board of Commissioners and will be implemented over the next few years. Importantly, the plan will turn the town's culturally important sites

\footnotetext{
3 These include the following: Edgecombe County, Upper Coastal Plain Council of Governments (UCPCOG), NC Office of Recovery and Resiliency (NCORR), NC Emergency Management (NCEM), Federal Emergency Management Agency (FEMA), United States Army Corps of Engineers (USACE), NC Commerce, Conservation Trust of NC, NC State University, Coastal Dynamics Design Lab, and East Carolina University.
}

into amenities that can be promoted via heritage-based tourism (Naylor et al. 2020). The town's few remaining historic structures that were damaged in 2016, including the senior center, town hall, and museum, are currently being rebuilt in place with wet floodproofing designs (i.e., modifications made to buildings to allow floodwaters to enter them in order to minimize damage) and materials, making them resilient to future flooding events. These sites, along with other historically significant structures and sites, such as Mount Zion Primitive Baptist Church and Princeville Elementary School, are also included in the Floodprint design.

Coupled with this effort to make the important historic sites in Princeville more resilient to flooding and to transition them to the town's heritage tourism assets, the town plans to relocate critical services such as the fire station to a newly acquired parcel of land adjacent to Princeville proper and out of the 100-year floodplain. After Hurricane Matthew, the state provided funding for the town to purchase the 53-acre site. To date (April 2021), the preliminary engineering work on the site has been completed, along with a master planning process with community input. Construction on the site will begin in 2021, with the first phase focused on developing the site's infrastructure. Through recent appropriations from the state, the town has acquired an additional 88-acre site. The town has hired a planning firm to do comprehensive land use planning, and this new site will be incorporated into that effort.

In early 2020 , the town was awarded nearly $\$ 40$ million to upgrade the levee and elevate highways from a mix of federal and state funds (Bonner 2020). Some long-term residents have advocated for the funding for this project for years and are relieved to see it finally come. While the upgraded levee will certainly help make Princeville less flood-prone, the town's strategic relocation of critical infrastructure and services indicate the understanding that although Princeville will never be safe from flooding, the town can proactively choose when and how to relocate to higher ground, without abandoning the important historical and cultural sites.

Other efforts, smaller in scale but no less significant, have contributed to the revitalization and beautification of Princeville and its vibrant history. In 2019, North Carolina State University professors oversaw the student creation of a mobile museum (a small structure on wheels that can be transported to various locations) to house a travelling exhibit (Graham 2020). Featured prominently on the museum's side are the numbers "1885," marking the town's incorporation date. Significantly, the mobile museum was the first physical structure to be rebuilt since Hurricane Matthew. The authors of this paper have developed two separate exhibits that are planned for display in the mobile museum, focusing on the town's history and community perceptions of resilience. Other projects include the rehabilitation of the town's Heritage Park and the approval of a farmer's market and the 
installation of "Welcome to Princeville" signs at the four primary entrances to the town. Additionally, projects to repair and improve the town's infrastructure, including the repair of the levee's floodgates, road paving, and the repair and improvement of the town's stormwater pipes, are planned or in progress.

In addition to the town's efforts, following Hurricane Matthew, a coalition of younger individuals organized a nonprofit, Freedom Organization and are galvanizing the youth to embrace plans for rebuilding housing, returning economic self-determination, and initiating new tourist and recreation venues. Their efforts include a revitalization of the Black farm and a series of town cleanup days. The group also initiated a homecoming celebration for summer 2020 which attracted interest from across the USA, but the COVID-19 outbreak resulted in a postponement to 2021 .

With future climate change impacts, increased flooding, and increased storm events, relocation becomes more and more inevitable; communal efforts and lobbies for buyouts, situated in their politics, will be more likely (Elliott et al. 2020). It remains an open question whether Princeville will be forced into this alternative. The recent efforts to keep the Princeville story alive through initiatives such as the mobile museum, plans for tourist venues, and a homecoming event are signs that intangible heritage-Princeville's uniqueness in collective memory-will continue to be vitally central to such decisions.

\section{Conclusions}

In the USA, racial, ethnic, and cultural minorities have systematically been pushed to the periphery of our landscapes, so they have had little choice but to build communities in vulnerable and risky spaces, such as in floodplains. It is precisely this reason that they are "allowed" to build in those places-because they are unwanted by those with power and influence. Given the hardships and struggles these groups have faced when establishing and sustaining cohesive communities in these areas often at risk from natural hazards (such as the risk of riverine flooding, as in Princeville), it is not surprising that people feel deep connections not only to other members of their communities, but also to the landscapes themselves. The current mitigation and buyout programs and policies in the USA are not designed, however, to take these deep connections to place into consideration (Marino 2018). Further, this is not just the case in Princeville, as those working in coastal Louisiana (Colten et al. 2018; Jessee 2020), New Orleans (Bullard Wright 2009; Phillips et al. 2012), and Alaska (Marino 2015) also illustrate.

This case study, therefore, provides critical insights for researchers and practitioners working on managed retreat issues, specifically in post-disaster contexts. It contributes to a growing call in the literature for the need to combine in-depth, case-by-case approaches with larger scale quantitative studies on disaster recovery and relocation to more fully understand what impacts individuals' and communities' willingness to participate in buyouts and managed retreat, as well as what the long-term impacts from these programs may be (Bukvic and Owen 2017; Binder et al. 2019). Such an integrated approach can assist with the development of adaptation strategies and policies that allow for consideration of communities' "distinct cultural, historical, institutional, and socioeconomic dimensions" (Bukvic and Owen 2017:120), including the critical roles that place attachment and place identity play in decision-making.

Princeville's story also exemplifies how place attachment can help drive adaptation and retreat (Amundsen 2015). Even in communities that have suffered catastrophic flooding events, such as Princeville, retreat does not have to be perceived only as a last and final option. Instead, retreat can be promoted as a way to proactively and strategically move vitally important facets of the community out of harm's way, so they can be preserved and continued. Critically, communities should have agency to do so in ways deemed effective and meaningful by the communities themselves, and not as policies forced upon them by external organizations.

Finally, the case study and narrative approach used here allow us to examine Princeville's experience over time, highlighting how complex and lengthy post-disaster processes often are as they happen in communities "on the ground." Further research can and should continue to interrogate the institutions and practices that are in place that perpetuate inequality and marginalization in post-disaster and managed retreat contexts. Although Princeville is still in the process of recovery and rebuilding, continued research with the town will further clarify whether their strategy of partial retreat can reduce future risks from flooding while also preserving community members' deep emotional commitment to the town's history and to honoring their ancestors' struggle for self-determination.

Acknowledgements We would like to thank the residents of Princeville, especially those who shared their stories with us through oral history interviews. We also are grateful to those who collaborated on the ECU REDE grant and helped facilitate our engagement with the community, including Dr. Glenda Knight (Princeville Town Manager), Linda Joyner (Princeville Mayor Pro Tem), Calvin Adkins, and Andrew DeIonno (Upper Coastal Plain Council of Governments). We would also like to thank the leaders of the Freedom Organization-Marquetta Dickens and Kendrick Ransome-for their collaboration on a grant from the North Carolina Humanities Council.

Funding Funding to support this research was provided by (1) East Carolina University's Division of Research, Economic Development, and Engagement (REDE) and (2) the North Carolina Humanities Council. 


\section{Declarations}

Conflict of interest The authors declare that they have no conflict of interest.

\section{References}

Adkins C (2020) Princeville celebrates $135^{\text {th }}$ birthday. Tar River Times, 20, Feb. http://tarrivertimes.com/princeville-celebrates-th-birth day-p1319-117.htm. Accessed 25 Aug 2020

Agyeman J, Devine-Wright P, Prange J (2009) Close to the edge, down by the river? Joining up managed retreat and place attachment in a climate changed world. Environ Plan A 41(3):509-513

Amundsen H (2015) Place attachment as a driver of adaptation in coastal communities in Northern Norway. Local Environ 20(3):257-276

Armstrong-Fumero F (2017) Legacies of space and intangible heritage: archaeology, ethnohistory, and the politics of cultural continuity in the Americas. Boulder: University Press of Colorado

Army Corps of Engineers (ACE) (2015) Princeville, North Carolina flood risk management integrated feasibility report and environmental assessment. Appendix F: other social effects. https://www. ucpcog.org/Princeville\% 20Levee\%20Integrated\%20Report\% 20FINAL\%20Draft\%20-\%2003\%2012\%2014.pdf. Accessed 17 Sept 2020

Bernard HR (2017) Research methods in anthropology: qualitative and quantitative approaches. Rowman \& Littlefield

Bidgood J (2016) A wrenching decision where black history and floods intertwine. The New York Times. December 9, 2016. https://www. nytimes.com/2016/12/09/us/princeville-north-carolina-hurricanematthew-floods-black-history.html

Binder SB, Baker CK, Barile JP (2015) Rebuild or relocate? Resilience and post disaster decision-making after Hurricane Sandy. Am J Commun Psychol 56(1-2):180-196

Binder SB, Barile JP, Baker CK, Kulp B (2019) Home buyouts and household recovery: neighborhood differences three years after Hurricane Sandy. Environ Hazards 18(2):127-145

Bonner L (2020) Historic NC town has long been promised federal flooding help. It's finally coming. News \& Observer. January 10, 2020. https://www.newsobserver.com/news/politics-government/ article239158333.html

Bowman B (1999) Princeville opts to rebuild dike instead of federal buyout. WRAL.com. https://www.wral.com/news/local/story/ 121121/. Accessed 27 Aug 2020

Bukvic A, Owen G (2017) Attitudes towards relocation following Hurricane Sandy: should we stay or should we go? Disasters 41(1):101-123

Bullard RD, Wright B (Eds.) (2009) Race, place, and environmental justice after Hurricane Katrina: struggles to reclaim, rebuild, and revitalize New Orleans and the Gulf Coast. Perseus Books

Cecelski D (2007) Delia Perkins: the waters came down. News \& Observer. https://www.ncpedia.org/listening-to-history/perkinsdelia. Accessed 18 Sept 2020

Cecelski D (2019) Cotton and steamboats: photographs from the Tar River, 1890-1900. https://davidcecelski.com/2019/02/17/cottonsteamboats-photographs-from-the-tar-river-1890-1900/. Accessed 27 Aug 2020

Cha-Jua SK (2000) America's First Black Town: Brooklyn, Illinois, 1830-1915. Urbana and Chicago: University of Illinois Press

Chamlee-Wright E, Storr VH (2009) “There's no place like New Orleans": sense of place and community recovery in the Ninth Ward after Hurricane Katrina. J Urban Aff 31(5):615-634
Chapman D (2002) Flood-ravaged Princeville going it alone. The Baltimore Sun. https://www.baltimoresun.com/news/bs-xpm2002-03-10-0203100269-story.html. Accessed 20 Sept 2020

Clarke D, Murphy C, Lorenzoni I (2018) Place attachment, disruption and transformative adaptation. J Environ Psychol 55:81-89

Clinton WJ (2000) Executive order 13146 - presidents council on the future of Princeville, North Carolina. Washington, DC: The White House. http://www.presidency.ucsb.edu/ws/index.php? pid=61638\#ixzz1bKPMGzWO. Accessed 14 Sept 2020

Coastal Dynamics Design Lab (n.d.) Princeville floodprint. https:// www.coastaldynamicsdesignlab.com/princeville-floodprint. Accessed 20 September 2020

Coastal Resilience Center (2020) Hurricane Matthew recovery Princeville. https://coastalresiliencecenter.unc.edu/crc-projects/ hurricane-matthew-recovery/hurricane-matthew-recovery-engag ement/hurricane-matthew-recovery-princeville/

Colten CE, Simms JR, Grismore AA, Hemmerling SA (2018) Social justice and mobility in coastal Louisiana, USA. Reg Environ Change 18(2):371-383

Crockett NL (1979) The Black towns. Lawrence: University of Kansas Press

de Vries DH (2017) Temporal vulnerability and the post-disaster 'window of opportunity to woo:' a case study of an AfricanAmerican floodplain neighborhood after Hurricane Floyd in North Carolina. Hum Ecol 45(4):437-448

Devine-Wright P (2013) Think global, act local? The relevance of place attachments and place identities in a climate changed world. Glob Environ Chang 23(1):61-69

Edgecombe County Census (1790) Colonial and State Records of North Carolina https://docsouth.unc.edu/csr/index.php/docum ent/csr26-0017. Accessed 27 Aug 2020

Elliott JR, Brown PL, Loughran K (2020) Racial inequities in the federal buyout of flood-prone homes: a nationwide assessment of environmental adaptation. Socius $6: 1-15$

Graham L (2020) The museum that tells Princeville's story. Our State. https://www.ourstate.com/the-museum-that-tells-princ evilles-story/. Accessed 15 Nov 2020

Greer A, Binder SB, Thiel A, Jamali M, Nejat A (2020) Place attachment in disaster studies: measurement and the case of the 2013 Moore tornado. Popul Environ 41(3):306-329

Groen JA, Polivka AE (2010) Going home after Hurricane Katrina: determinants of return migration and changes in affected areas. Demography 47(4):821-844

Jessee N (2020) Community resettlement in Louisiana: learning from histories of horror and hope. In Louisiana's Response to Extreme Weather (pp. 147-184). Cham: Springer

Knight CR, Auld LWS (2013) African American heritage guide: Rocky Mount, Tarboro, Edgecombe County. Perry-Weston Historical Institute

Koslov L (2016) The case for retreat. Publ Cult 28(2):359-387

Lall U, Johnson T, Colohan P, et al (2018) Water. In D. R. Reidmiller, C. W. Avery, D. R. Easterling, K. E. Kunkel, K. L. M. Lewis, T. K. Maycock, \& B. C. Stewart (Eds.), Impacts, risks, and adaptation in the United States: fourth national climate assessment, Volume II (pp. 145-173). Washington DC: U.S. Global Change Research Program. https://doi.org/10.7930/ NCA4.2018.CH3

Lewicka M (2011) Place attachment: how far have we come in the last 40 years? J Environ Psychol 31(3):207-230

Listening to History (2003) Rudolph Knight: history right here. The News and Observer, 9 March 2003. https://www.ncpedia.org/liste ning-to-history/knight-rudolph. Accessed 27 Aug 2020

Mach KJ, Kraan CM, Hino M, Siders AR, Johnston EM, Field CB (2019) Managed retreat through voluntary buyouts of flood-prone properties. Sci Adv 5(10) 
Marino E (2015) Fierce climate, sacred ground: an ethnography of climate change in Shishmaref. Alaska: University of Alaska Press

Marino E (2018) Adaptation privilege and voluntary buyouts : perspectives on ethnocentrism in sea level rise relocation and retreat policies in the US. Glob Environ Chang 49(January):10-13. https:// doi.org/10.1016/j.gloenvcha.2018.01.002

Martin A (2019) Race, place, and resilience: social equity in North Carolina's post-disaster buyout program. Dissertation, University of North Carolina at Chapel Hill

Mobley J (1986) In the Shadow of White Society: Princeville, a Black Town in North Carolina, 1865-1915. North Carolina Hist Rev 63(3):340-384. Retrieved August 27, 2020, from http://www.jstor. org/stable/23518785

Naylor L, Fall V, \& Fox A (2020) The power of place in disaster recovery: heritage-based practice in the post-Matthew landscape of Princeville, North Carolina. In Parks Stewardship Forum (Vol. 36, No. 1)

North Carolina Department of Environmental Quality (NCDEQ) (2020) North Carolina climate risk assessment and resilience plan. https://files.nc.gov/ncdeq/climate-change/resilience-plan/2020Climate-Risk-Assessment-and-Resilience-Plan.pdf. Accessed 10 Sept 2020

North Carolina Emergency Management (NCEM) (2017a) Hazard Mitigation Projects. North Carolina: Raleigh

North Carolina Emergency Management (NCEM) (2017b) Hurricane Matthew Resilient Redevelopment Plan, Edgecombe County. NCEM. https://files.nc.gov/rebuildnc/documents/matthew/rebui ldnc_edgecombe_plan_combined.pdf

Patricola CM, Wehner MF (2018) Anthropogenic influences on major tropical cyclone events. Nature 563(7731):339-346

Phillips B, Stukes P, \& Jenkins P (2012) Freedom Hill is not for saleand neither is the lower ninth ward. J Black Stud 43(4):405-426. Retrieved August 27, 2020, from http://www.jstor.org/stable/ 23215223

Seebauer S, Winkler C (2020) Should I stay or should I go? Factors in household decisions for or against relocation from a flood risk area. Glob Environ Chang 60:102018

Siders AR (2019) Social justice implications of US managed retreat buyout programs. Clim Change 152(2):239-257

Siders AR (2019) Managed retreat in the United States. One Earth 1(2):216-225

Siders AR, Keenan JM (2020) Variables shaping coastal adaptation decisions to armor, nourish, and retreat in North Carolina. Ocean Coast Manag 183:105023
Smallwood JM (1981) Time of hope, time of despair: Black Texans during reconstruction. Port Washington: Kennikat

Smith GP, Wenger D (2007) Sustainable disaster recovery: operationalizing an existing agenda. In: Rodriguez H, Quarantelli EL, Dynes RR (eds) Handbook of Disaster Research. New York: Springer, pp 234-257

State of North Carolina (1885) Laws and resolutions of the State of North Carolina, passed by the General Assembly at its session [1885]. https://digital.ncdcr.gov/digital/collection/p249901coll22/ id/200754. Accessed 15 Jan 2021

Taylor Q (1995) "The Black Towns." In Jack Salzman, David Lionel Smith, and Cornel West, eds. Encyclopedia of African American Culture and History. New York: Macmillan Publishing Company

Tilove J (2005) Flooded town reborn as black icon. The Seattle Times. February 17, 2005. https://www.seattletimes.com/nation-world/ flooded-town-reborn-as-black-icon/. Accessed 29 Aug 2020

Town of Princeville (n.d.) https://www.townofprinceville.com/townof-princeville-nc-history.html. Accessed 29 Aug 2020

Traylor C (2017) Princeville, N.C., refuses to be swept away. The Municipal. http://www.themunicipal.com/2017/03/princevillen-c-refuses-to-be-swept-away/. Accessed 27 Aug 2020

Trentelman CK (2009) Place attachment and community attachment: a primer grounded in the lived experience of a community sociologist. Soc Nat Resour 22(3): 191-210

Turner JK and John LB (1850) History of Edgecombe County, North Carolina. Raleigh, Edwards \& Broughton Printing Company:1920. https://archive.org/stream/historyofedgecom00turn/ historyofedgecom00turn_djvu.txt. Accessed 8-27-2020

URS Group Inc (2001) Final report: historic architectural resources survey of Princeville, North Carolina. Vol. 1. Prepared for the Federal Emergency Management Agency, Region IV-Atlanta, Georgia. April 2001

U.S. Census Bureau (2020) https://www.census.gov/data.html. Accessed 5 Sept 2020

Wyllie E (2012) Defining eastern North Carolina upriver steamboats through Tar River: archaeology and history. Unpublished MA Thesis, East Carolina University. http://hdl.handle.net/10342/ 3843. Accessed 27 Aug 2020

Yoon I (2009) A mixed-method study of Princeville's rebuilding from the flood of 1999: lessons on the importance of invisible community assets. Soc Work 54(1):19-28

Publisher's note Springer Nature remains neutral with regard to jurisdictional claims in published maps and institutional affiliations. 